UCRL-ID-139508

\title{
Extended Deterrence, Nuclear Proliferation, and START III
}

\author{
R. D. Speed
}

\section{June 20, 2000}

U.S. Department of Energy

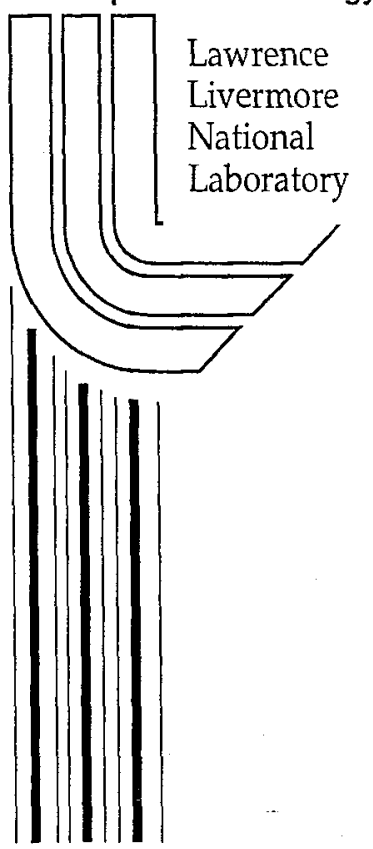

The views presented here are those of the author and do not represent those of Lawrence Livermore National laboratory, the University of California, the United States Government, or any other institution. 



\section{DISCLAIMER}

This document was prepared as an account of work sponsored by an agency of the United States Government. Neither the United States Government nor the University of California nor any of their employees, makes any warranty, express or implied, or assumes any legal liability or responsibility for the accuracy, completeness, or usefulness of any information, apparatus, product, or process disclosed, or represents that its use would not infringe privately owned rights. Reference herein to any specific commercial product, process, or service by trade name, trademark, manufacturer, or otherwise, does not necessarily constitute or imply its endorsement, recommendation, or favoring by the United States Government or the University of California. The views and opinions of authors expressed herein do not necessarily state or reflect those of the United States Government or the University of California, and shall not be used for advertising or product endorsement purposes.

Work performed under the auspices of the U. S. Department of Energy by the University of California Lawrence Livermore National Laboratory under Contract W-7405-Eng-48.

This report has been reproduced

directly from the best available copy.

Available to DOE and DOE contractors from the

Office of Scientific and Technical Information

P.O. Box 62, Oak Ridge, TN 37831

Prices available from (423) 576-8401

http://apollo.osti.gov/bridge/

Available to the public from the

National Technical Information Service

U.S. Department of Commerce

5285 Port Royal Rd.,

Springfield, VA 22161

http://www.ntis.gov/

OR

Lawrence Livermore National Laboratory

Technical Information Department's Digital Library

http://www.llnl.gov/tid/Library.html 



\section{Table of Contents}

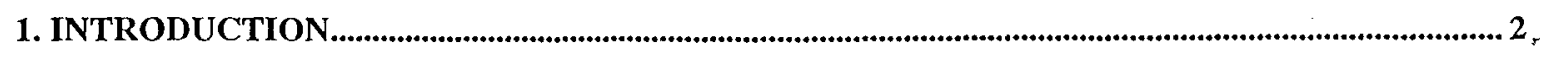

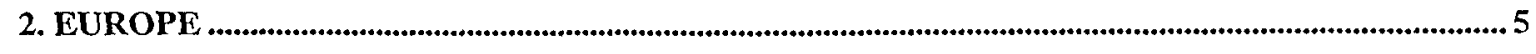

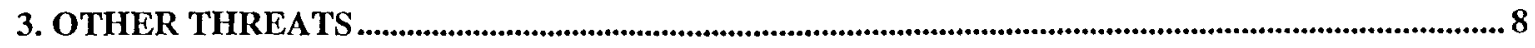

3.1 EAST ASIA

3.1.1 People's Republic of China (PRC)

3.1.2 Democratic People's Republic of Korea (DPRK) ........................................................ 11

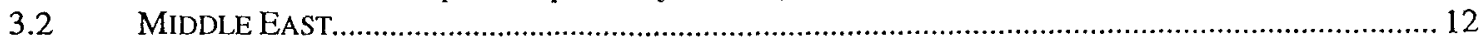

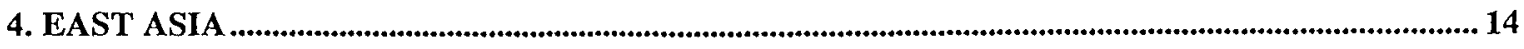

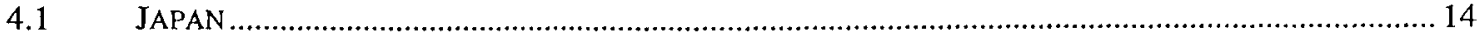

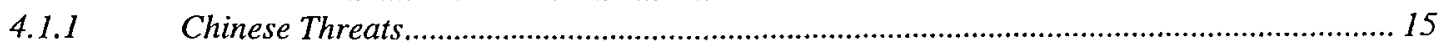

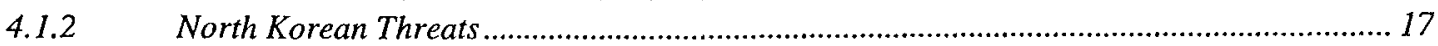

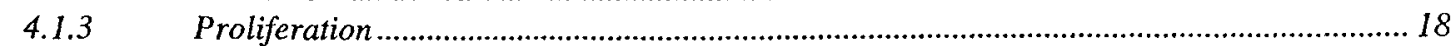

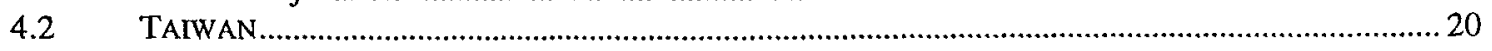

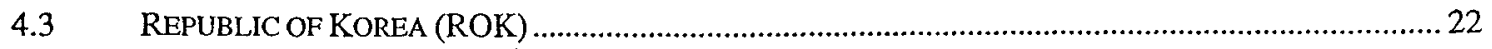

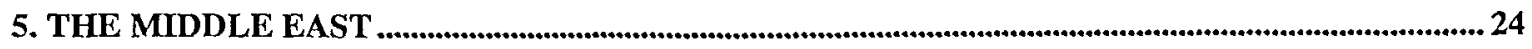

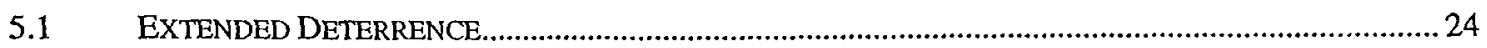

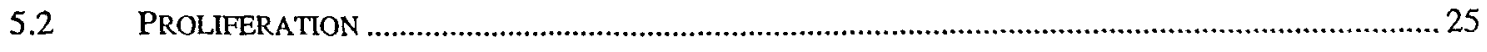

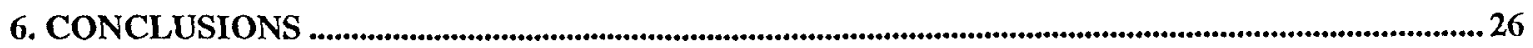




\section{Introduction}

Early in the Cold War, the United States adopted a policy of "extended nuclear deterrence" to protect its allies by threatening a nuclear strike against any state that attacks these allies. This threat can (in principle) be used to try to deter an enemy attack using conventional weapons or one using nuclear, chemical, or biological weapons. The credibility of a nuclear threat has long been subject to debate and is dependent on many complex geopolitical factors, not the least of which is the military capabilities of the opposing sides.

The ending of the Cold War has led to a significant decrease in the number of strategic nuclear weapons deployed by the United States and Russia. START II, which was recently ratified by the Russian Duma, will (if implemented) reduce the number of deployed strategic nuclear weapons on each side to 3500 , compared to a level of over 11,000 at the end of the Cold War in 1991. The tentative limit established by Presidents Clinton and Yeltsin for START III would reduce the strategic force level to 2000-2500. However, the Russians (along with a number of arms control advocates) now argue that the level should be reduced even further - to 1500 warheads or less.

The conventional view is that "deep cuts" in nuclear weapons are necessary to discourage nuclear proliferation. Thus, as part of the bargain to get the non-nuclear states to agree to the renewal of the Nuclear Non-Proliferation Treaty, the United States pledged to work towards greater reductions in strategic forces. Without movement in the direction of deep cuts, it is thought by many analysts that some countries may decide to build their own nuclear weapons. Indeed, this was part of the rationale India used to justify its own nuclear weapons program.

However, there is also some concern that deep cuts (to 1500 or lower) in the U.S. strategic nuclear arsenal could have the opposite effect. The fear is that such cuts might undermine extended deterrence and cause a crisis in confidence among U.S. allies to such an extent that they could seek nuclear weapons of their own to protect themselves.

\section{Background}

The theory of extended deterrence originated in the United States in the early-1950s in the context of the use of long- or intermediate-range nuclear forces to deter or defeat a Soviet invasion of Western Europe. ${ }^{1}$ At that time, the Soviet Union possessed few longrange nuclear delivery systems, but very large conventional forces. Since the United States was relatively invulnerable to nuclear attack, NATO opted for a policy of "massive retaliation" as an "inexpensive" means to deter a Soviet conventional attack against Western Europe. That is, if the Soviet Union invaded Western Europe, the United States threatened to initiate massive nuclear attacks against the Soviet homeland that would eventually lead to the defeat and the destruction of the invader. Thus, America's nuclear deterrent capability was "extended" to cover its NATO allies.

However, by at least the late-1960s, it had become clear that the Soviets had achieved a second-strike retaliatory capability (i.e., they had enough survivable strategic forces to

\footnotetext{
'Stephen Prowse and Albert Wohlstetter, "Stability in a World with More Than Two Countries," Beyond START?, University of California, IGCC Policy Paper No. 7, 1988.
} 
delivery a devastating counterattack on the American homeland). Thus, a state of mutual strategic deterrence came into existence, and the threat of initiating coercive nuclear strikes against the Soviet Union (particularly Soviet cities) lost much of its credibility.

Since building a large enough conventional force to defeat an invasion was deemed by NATO to be economically and politically infeasible, U.S. NATO policy from the late1960 s centered around trying somehow to restore the credibility of the extended deterrent threat of initiating a nuclear strike against the Soviet homeland in the event of a conventional force invasion. This led to a continuous search for credible U.S. nuclearstrike options ${ }^{2}$ and war-winning capabilities and drove much of U.S. nuclear force planning and strategy. However, even the deployment of over 10,000 nuclear warheads could not remove the doubts about the credibility of U.S. threats to initiate nuclear strikes against a well-armed Soviet Union or Russia.

During the Cold War, the United States tried to spread its nuclear umbrella over nonNATO states as well. But the massive U.S. nuclear arsenal seemed to have very little capability to prevent non-nuclear states from attacking U.S. allies and friends in South Korea, South Viet Nam, or Kuwait. Moreover, as part of its policy of discouraging the proliferation of nuclear weapons, the United States since 1978 has explicitly promised not to use nuclear weapons against non-nuclear states that are party to the Nuclear NonProliferation Treaty, further limiting the scope of extended nuclear deterrence. ${ }^{3}$

Whether this guarantee applies to the use of chemical or biological weapons by nonnuclear states is unclear. While the U.S. commitment of "no nuclear attack" makes no exceptions for the use of these weapons, the Bush and Clinton Administrations have been very ambiguous on the topic. At any rate, the credibility and effectiveness of such threats (unless the United States were attacked) is uncertain. ${ }^{4}$ Of course, some believe that implied U.S. nuclear threats prevented Iraq from using chemical or biological weapons in the Gulf War. However, Iraq's reluctance may be more attributable to Israel's nuclear arsenal and to Iraq not wanting to further antagonize Arab countries by attacking Saudi

\footnotetext{
${ }^{2}$ These strikes would probably have been limited in scope initially, but the strategy required that the United States possess the capability to be able to escalate to an all-out counterforce attack if necessary.

${ }^{3}$ To induce non-nuclear countries to sign the NPT of 1968, the United States, Great Britain, and the Soviet Union asserted their intentions to seek immediate United Nations Security Council actions to provide assistance to any non-nuclear weapons signatory of the NPT that was the object of nuclear aggression or threats. And in 1978, in connection with the UN Special Session on Disarmament, President Carter (through his Secretary of State, Cyrus Vance) gave explicit "negative" security assurances to these countries when he declared that "The United States will not use nuclear weapons against any non-nuclear weapons state party to the NPT...." Arms Control and Disarmament Agency, Arms Control and Disarmament Agreements: Texts and History of Negotiations, 1982, p. 86.

${ }^{4}$ The United States might have considerable difficulty in determining which targets to retaliate against. To threaten the military-industrial complex might seem to be an effective deterrent, except that it would result in the deaths of thousands (perhaps millions) of innocent civilians. In this case, the United States would be in the position of declaring that the use of chemical and biological weapons is morally repugnant, even in retaliation, while at the same time threatening to use nuclear weapons in a no less morally repugnant manner. The moral and political acceptability - and hence credibility - of this approach is doubtful. (Limited strikes against isolated military targets might be able to limit casualties, particularly if new, smaller weapons were developed. But such attacks are unlikely to be militarily decisive and hence not an effective deterrent. In addition, conventional attacks on such targets using modern weapons would probably be just as effective.)
} 
Arabia with such weapons. Of course, if the United States actually contemplated using nuclear weapons in this context, it would have been with the knowledge that its opponent could not retaliate with a counterstrike. In future situations, this may not always be the case.

\section{The Future of Extended Deterrence and Proliferation}

A decade after the end of the Cold War and the collapse of the Soviet Union, the United States still finds itself committed around the world to the defense of many countries, perhaps even more than during the Cold War. The United States now limits its nuclear umbrella to deterring nuclear-armed states and (perhaps) states armed with biological or chemical weapons. However, as more potential U.S. opponents develop weapons of mass destruction and the capability to strike at the U.S. homeland, the credibility of U.S. extended nuclear deterrence may be increasingly questioned.

In the following sections, several potential regions of conflict where the United States has defense commitments will be examined. In each region, the issue of the credibility of extended deterrence and, in particular, whether the credibility depends on the force levels agreed to in START III is addressed. In addition, the general question of nuclear proliferation by U.S. allies is also briefly examined for each region. Particular emphasis is given to the Asia-Pacific region because of its potential instability and because U.S. allies there could relatively easily develop nuclear weapons. 


\section{Europe}

As noted in the introduction, the use of nuclear threats to deter a Russian conventional attack in Europe seems (to many observers) to lack credibility because Russia can respond to a U.S. nuclear strike with a devastating blow of its own. Reducing the number of strategic nuclear warheads on each side to 2500 or 1500 is unlikely to change this basic calculus one way or the other unless the United States could obtain a disarming first-strike capability, something the Russians are unlikely to allow to happen. ${ }^{5}$

Fortunately, nuclear threats to deter a conventional attack no longer appear to be necessary. Today, even if Russia suddenly became hostile and aggressive, its conventional forces are in a state of collapse. If in the future Russia should rebuild its conventional forces and begin to take aggressive actions against its neighbors (most likely in an attempt to reconstitute part of the former-Soviet Union into a new Great Russian state), the West will likely have plenty of time to react. Considering that European-NATO alone has three times the population and many more times the economic output of Russia, providing a conventional defense to deter a conventional attack should be quite feasible. Indeed, NATO policy today strongly de-emphasizes the nuclear component of its defense strategy, and nuclear weapons are now viewed only as weapons of last resort. Some NATO members have also pushed for an explicit "no first use" nuclear policy in Europe, which of course would officially negate the policy of extended deterrence against a conventional attack.

But what about a nuclear attack by a future aggressive Russia? As long as NATO has survivable nuclear weapons, the probability of a Russian nuclear attack on Western Europe would appear to be extremely low. Even at the height of the Cold War, few strategists were worried about a Warsaw Pact nuclear attack in Europe. The primary concern was that NATO would be faced with a situation where it was losing a conventional war and the only apparent alternative would be to initiate a nuclear war. Much of the dilemma of NATO policy was how to make the threat of the first use of nuclear weapons credible, since starting a nuclear war always has the potential for an uncontrollable, suicidal escalation. The dilemma that a future aggressive Russia would face would seem even worse. Russia would have to coldly consider the risks of initiating a nuclear war-not for survival, but to gain some limited, dubious ${ }^{6}$ objective.

Initiating a nuclear attack against a nuclear-armed alliance would obviously be risking great loss, perhaps the very existence of Russia. The United States has for over 50 years committed itself to the defense of Europe, clearly showing that it views its long-term security to be intimately entwined with the fate of Western Europe. Moreover, any

\footnotetext{
${ }^{5}$ Today, Russian strategic forces are in a state of disarray, and the United States could - in theory - come close to disarming them. However, the Russians have a policy of launching their ICBMs on warning of an incoming attack which could thwart any U.S. attack. Moreover, even though the Russians reportedly have only one or two strategic submarines at sea, these submarines could do massive damage to the U.S. homeland. Undoubtedly, if some future aggressive Russian state contemplated war in Europe, an important objective would be to increase the survivability of its strategic forces even further, perhaps by deploying more mobile ICBMs and keeping more submarines at sea.

${ }^{6}$ The Soviet experience in Eastern Europe for over 40 years demonstrated that holding an empire is generally not economically advantageous.
} 
nuclear attack by Russia on NATO forces would undoubtedly involve the deaths of many American soldiers, assuring that some response could be expected. The retaliation would come whether a START III agreement allowed 2500 warheads or 1500 . While the NATO response would likely be designed to limit escalation if possible, as long as the United States (and France and the United Kingdom) retained survivable weapons, the Russians would have little doubt that a nuclear war would ensue. And even if NATO's retaliatory strike were confined to military targets, it could result in millions of casualties and vast economic destruction in Russia. This would seem to far overshadow any potential advantage to be gained by trying to conquer all or part of Europe.

Of course, Russia could try to confine the nuclear war to the battlefield in order to limit the risks of escalation. However, even if some limited tactical advantage were achieved, the inevitable retaliatory strike would probably offset that advantage. ${ }^{7}$ Moreover, with nuclear weapons detonating in Western Europe, NATO is unlikely to restrict its counterattack to NATO territory. The leadership of Russia could certainly not count on their homeland remaining a nuclear sanctuary. At the very least, limited retaliatory nuclear strikes could be expected against Russian military centers being used to support the invasion.

Thus, it would be extremely difficult for Russian planners to predict with confidence that they could in fact "win" a nuclear war if they initiated it. More importantly, the "collateral" damage and the risks of a runaway escalation from strikes and counterstrikes by U.S., French, and British nuclear forces would seem to far outweigh any prospect of achieving a military victory and act as a strong deterrent to any aggressive action.

\section{Proliferation}

In the post-Cold War world, Western Europe probably feels more secure than it has in almost a century. With no major military threats facing Europe and with the NATO alliance still intact, the question of nuclear proliferation seems remote. Few European countries have ever even considered developing nuclear weapons. And the country perhaps of most concern, Germany, is firmly embedded in NATO and the European Union with little reason to seek an independent path to security. Although Germany has a strong industrial base and is easily capable of producing nuclear weapons, it has an antinuclear Social Democratic government and a population that is strongly anti-nuclear. Instead of deep cuts in strategic weapons producing a crisis in confidence in the U.S. commitment to NATO, Germany (like most NATO countries) is strongly in favor of such cuts. Indeed, it is U.S. actions such as the proposed National Missile Defense system and the rejection of the Comprehensive Test Ban Treaty that are causing Europeans to worry about the curtailing of disarmament efforts and perhaps even the eventual triggering of a

\footnotetext{
${ }^{7}$ This scenario (however unlikely) does emphasize that START III should eliminate the enormous nonstrategic nuclear weapons advantage that Russia presently has - perhaps many thousands of non-strategic nuclear weapons in Europe compared to only a few hundred for the United States. If this imbalance were allowed to persist, the perception of a significant military advantage might evolve over time in Europe. With strategic forces reduced to only 1500 , the non-strategic forces could begin to take on considerably more weight. Whether this could be translated into military advantage is uncertain, but when it comes to deterrence, NATO should err on the side of caution and not give Russian planners any reason to think they might be able to achieve an advantage in a crisis. (Under START III, the Russians might be allowed enough non-strategic weapons to equal the total number of nuclear weapons of the British and French plus the non-strategic weapons of the United States.)
} 
UCRL-ID-139508

Page 7 new arms race with Russia, subverting efforts to keep Russia on a path of reconciliation
with the West. 


\section{Other Threats}

The credibility of the U.S. extended nuclear deterrence policy will depend to a large degree on the capability of the other side to retaliate against a U.S. nuclear strike, i.e., on whether they can deter the United States with nuclear, biological, or chemical threats of their own. This section examines the potential threat outside of Europe during the next decade.

\subsection{East Asia}

Only two countries in East Asia pose a threat to U.S. interests to such an extent that it might call U.S. nuclear weapons into play: China and North Korea.

\subsubsection{People's Republic of China (PRC)}

China, while doing much to free its economic system from state control, remains an authoritarian one-party state. However, being authoritarian does not necessarily equate with being aggressive. According to Chinese Defense Minister General Chi Haotian, "China follows a 'defensive defense policy.'... The basic goal of China's defense policy is to consolidate national defense, resist foreign aggression, safeguard state sovereignty over territorial land, air, and water and maritime rights and interests and maintain national unity and security. The People's Liberation Army (PLA) of China follows a strategy of 'active defense,' that is, a principle of self-defense and striking only after being attacked is followed at the strategic level... [Moreover,] China is the only nuclear power that has undertaken not to be the first to use nuclear weapons under any circumstances and unconditionally not to use or threaten to use nuclear weapons against non-nuclear-weapon states."

As part of its strategy, China appears to have adopted a policy of "minimum" or "finite" nuclear deterrence to prevent the United States, Russia, or any other nuclear power from initiating attacks against the Chinese homeland or from using nuclear weapons to intimidate China. To carry out what is proclaimed to be a purely second-strike strategy, the Chinese have a small number of ICBMs and a moderate number of shorter-range missiles capable of delivering nuclear warheads to the United States, Russia, India, Japan, Taiwan, and other countries in Asia. The small size of the ICBM force dictates a strategy of targeting cities rather than military forces. ${ }^{9}$ China's modernization plans for the next decade indicate a shifting to mobile ballistic missiles to insure the survivability of its nuclear forces.

Many analysts agree that China has chosen to concentrate on improving its economy and needs a peaceful international atmosphere to make progress. For example, Selig Harrison, a senior scholar at the Woodrow Wilson International Center, stated at a recent conference that "China's conventional force posture and nuclear weapons deployments are defensive in character and are likely to remain so in the absence of grave

\footnotetext{
8 "Chinese Defense Minister Elaborates China's Defense Policy," Dec. 10, 1996, talk at the U.S. National Defense University, http://www.china-embassy.org.

${ }^{9}$ According to the National Intelligence Council, China's "doctrine requires only that it be able to hold a significant portion of an aggressor's population at risk." National Intelligence Council, "Foreign Missile Developments and the Ballistic Missile Threat to the United States through 2015," September 1999, p. 3.
} 
provocations." ${ }^{10}$ The general consensus is that the most likely "provocation" that would reverse this policy is a declaration of independence by Taiwan, which is considered by the People's Republic of China to be an integral part of China (and is recognized as such ${ }^{r}$ by the United States).

Reunification of Taiwan with the mainland remains a high priority with China. While China has generally insisted that it supports only a peaceful reunification, it has recently become quite concerned about the growth of political forces in Taiwan supporting some form of independence. Thus, in February of this year, China issued a White Paper which indicated that it would not be willing to wait forever for negotiations on peaceful reunification to begin. ${ }^{11}$ Many observers believed that the primary purpose of the paper was to frighten voters away from voting for Presidential candidate Chen Shui-bian, who in the past had expressed support for an independent Taiwan (although he has since backed away from this position). ${ }^{12}$

In addition to the question of Taiwan, some analysts see the possibility of conflict with China in the South China Sea. Virtually all of the Middle Eastern oil bound for Japan, South Korea, and Taiwan passes through the South China Sea. There are two groupings of about a thousand islands, reefs and rocks in the South China Sea known as the Spratlys and the Paracels. These are claimed in part or in whole by seven governments: China, Taiwan, Vietnam, the Philippines, Malaysia, Brunei, and Indonesia. China first claimed the Spratlys in 1987, although later a Chinese scholar, Chen Jie, asserted that "the Spratly archipelago has been part of the motherland's territory since ancient times. ${ }^{.13}$ Whether any of these disputes will lead to conflict and hence pose a threat to the sea lanes is very uncertain. China, for its part, claims that it only seeks a peaceful resolution to these disputes, and moreover that it "has never interfered with the freedom of passage of foreign vessels and aircraft in this area, nor will ever do so in the future." ${ }^{14}$ If nevertheless conflict arose, it is not clear that the United States would be drawn into such disputes, since its security commitments in this area are minimal or nebulous at best:

10 "The PRC at 50: China's Future Examined," Cato Policy Report, November/December 1999, Vol. 11, No. 6, p.1.

11 "The Chinese government remains firm in adhering to 'peaceful reunification' and 'one country, two systems'.... However, if a grave turn of events occurs leading to the separation of Taiwan from China in any name, or if Taiwan is invaded and occupied by foreign countries, or if the Taiwan authorities refuse, sine die, the peaceful settlement of cross-Straits reunification through negotiations, then the Chinese government will be forced to adopt all drastic measures possible, including the use of force, to safeguard China's sovereignty and territorial integrity and fulfill the great cause of reunification. The Chinese government and people absolutely have the determination and ability to safeguard China's sovereignty and territorial integrity, and will never tolerate, condone or remain indifferent to the realization of any scheme to divide China. Any such scheme is doomed to failure." "White Paper - The One-China Principle and the Taiwan Issue," The Taiwan Affairs Office and Information Office of the State Council, February 21, 2000, http://www.china-embassy.org.

${ }^{12}$ In a three-way race, Chen won the election.

${ }^{13}$ Chalmers Johnson, "The Chinese Way," The Bulletin of the Atomic Scientists, Jan/Feb 1997, Vol. 53, No. 1.

14 "The Question of the South China Seas," http://www.china-embassy.org. 


\section{Threats to the United States}

According to the National Intelligence Council (NIC), by " 2015 , China is likely to have tens of missiles capable of targeting the United States, including a few tens of more survivable, land- and sea-based mobile missiles with smaller nuclear warheads...."15

Currently, the only threat to the U.S. homeland by Chinese strategic forces is a force of about 20 CSS-4 ICBMs which carry single large-yield warheads. These liquid-fueled silo-based missiles are normally not on alert. However, in a crisis situation, the missiles could be put on alert and fired at U.S. cities on warning of an incoming attack.

China is also developing two new road-mobile, solid-propellant ICBMs.

The DF-31 ICBM was first flight tested in August 1999. This two-stage missile is estimated to have a range of about $8,000 \mathrm{~km}$, and, according to the NIC, it will be targeted primarily against Russia and Asia. However, with this range, the DF-31 will also be able to hit targets along the entire U.S. West Coast and in several northern Rocky Mountain states. Deployment of this missile is expected early in this decade.

A test of a longer-range ICBM (often designated as DF-41) is expected within the next several years. This missile is expected to be a three-stage mobile missile with a range of about $12,000 \mathrm{~km}$, and thus it will be capable of targeting the entire United States. The missile might be deployed by around 2010 .

In addition, testing of the new JL-2 SLBM is expected within the next decade. It will probably have a range of about $8,000 \mathrm{~km}$ (being the naval version of the DF-31), and thus will have the capability to attack the United States from areas near China. Being submarine based, the JL-2 will be able to attack the United States from different azimuths and at shorter ranges, allowing it to circumvent the U.S. National Missile Defense (NMD) system, at least as the NMD is now planned. ${ }^{16}$ A new missile-carrying submarine (the Type 094) is reportedly under construction and could be ready for service by $2006 .{ }^{17}$

China is also developing land-attack cruise missiles for theater warfighting and strategic attack. ${ }^{18}$ The first deployment is likely to be on bombers in the next few years. A submarine-launched version could also be produced eventually.

\section{Shorter-Range Threats}

The Chinese have deployed two new modern short-range ballistic missiles (SRBMs). ${ }^{19}$ The DF-11 (M-11/CSS-7) is the Chinese replacement for the Scud-series of missiles. This solid-fueled, highly mobile missile has a range of about $300 \mathrm{~km}$. The DF-15 (M-

\footnotetext{
${ }^{15}$ National Intelligence Council, op. cit., p. 2.

${ }^{16}$ NMD was designed to defeat warheads delivered by long-range ICBMs originating from "rogue" states such as North Korea, Iran, and Iraq - none of which are expected to have the capability to deploy submarine-launched ballistic missiles. Because the initial deployment of NMD will be in Alaska, defeating SLBMs with short flight times (compared to ICBMs) would be very difficult, particularly if launched at targets in the southern part of the country. "[A]s the Clinton Administration itself has acknowledged, the national missile defense being developed would be completely useless against such short-range missiles, which would hit their targets before interceptors could reach them." Lisbeth Grounlund and David Wright, "What They Didn't Do," The Bulletin of the Atomic Scientists, Nov/Dec 1998, Vol. 54, No. 6, p. 50.

${ }^{17}$ FYEO Newsletter, December 5, 1999.

${ }^{18}$ Federation of American Scientists, Nuclear Forces Guide, http://www.fas.org.

${ }^{19}$ Ibid.
} 
9/CSS-6) is a sophisticated solid-fueled, single-stage mobile missile with a reaction time of about 30 minutes. It has a range of $600 \mathrm{~km}$ and was the missile launched from southern China into the waters off Taiwan in 1995 and 1996 in an attempt to influence the Taiwanese elections.

China has also deployed a new, mobile, solid-fueled medium-range ballistic missile (MRBM), the CSS-5 (DF-21). It has a range of about $2000 \mathrm{~km}$ and thus is capable of hitting targets in Russia, India, Taiwan, Japan, and other parts of East Asia. China's older missiles assigned to this role are the MRBM CSS-2 with a range of about $3000 \mathrm{~km}$ and the intermediate-range (or limited-range ICBM) CSS-3 with a range of about 5000-6000 $\mathrm{km}$, some of which are likely to be retired over time.

\subsubsection{Democratic People's Republic of Korea (DPRK)}

North Korea remains an isolated dictatorship that poses a potential military threat to South Korea. The Intelligence Community estimates that after China and Russia, North Korea is the country most likely to develop ICBMs capable of threatening the United States in the next 15 years. ${ }^{20}$ North Korea already has missiles that can threaten South Korea and Japan.

It is believed that North Korea could have $6-12 \mathrm{~kg}$ of separated plutonium, enough to possibly produce one or two nuclear weapons. ${ }^{21}$ In addition, "North Korea possesses [chemical and] biological weapons production and dispensing technology, including the capability to deploy chemical or biological weapons on missiles."22

Today, North Korea has a large number of Scud missiles capable of striking targets throughout South Korea. It also began deploying in the late-1990s the liquid-fueled No Dong mobile missile. The No Dong has a range of $1300 \mathrm{~km}$ and thus can cover most of Japan.

North Korea has now developed a new variant of the No Dong called the Taepo Dong (TD) -1 . The two stage version of the TD-1 has a range of about $2000 \mathrm{~km}$, easily covering all of Japan and most of Taiwan. On August 31, 1998, North Korea attempted to launch a satellite on a TD -1 missile, using a solid-fueled third stage. ${ }^{23}$ While the third-stage failed on this test, the launch made it clear that North Korea has made considerable progress in developing long-range missile capabilities, including some aspects of ICBM development, such as multiple-stage separation. ${ }^{24}$

If the TD-1 "had an operable third stage and a reentry vehicle, a converted Taepo Dong-1 SLV could deliver a light-payload to the United States. In these cases, about two-thirds of the payload mass would be required for the reentry vehicle structure. The remaining mass

\footnotetext{
${ }^{20}$ National Intelligence Council, op. cit., p. 3.

${ }^{21}$ North Korea Advisory Group, Report to the Speaker of the House of Representatives, November 1999 , p. 8 . 
is probably too light for an early generation nuclear weapon but could deliver biological or chemical (BW/CW) warfare agent." 25

The North Koreans are also working on a two-stage Taepo Dong-2 missile which could deliver a several-hundred kilogram payload to Alaska and Hawaii, and a lighter payload to the western half of the United States. A three-stage Taepo Dong-2 could deliver a several-hundred kilogram payload to anywhere in the United States. ${ }^{26}$ The Taepo Dong-2 could be tested at any time, but currently there is a moratorium on missiles tests as the North Koreans negotiate with the United States on diplomatic recognition and the lifting of economic sanctions.

\subsection{Middle East}

Iran and Iraq would seem to be the Middle Eastern countries most capable of developing long-range missiles in the next decade or so. Of course, short-range and medium-range missiles are available to Iran now or will be in the near future. In addition, both countries have the technical capability to produce chemical and biological weapons. Iran also is thought to be seeking the capability to produce nuclear weapons. ${ }^{27}$

\section{Iran}

The Intelligence Community believes that Iran is the country in this region most likely to develop long-range missiles in the next 15 years. ${ }^{28}$ There are several possible paths to such a development.

Iran could test an ICBM that could deliver a several hundred kilogram payload to many parts of the United States in the later-half of this decade if it has Russian technology and assistance.

Alternatively, Iran could pursue a Taepo Dong-type ICBM. Most analysts believe that it could test such an ICBM, possibly with North Korean assistance, in the next few years.

Finally, analysts believe that Iran is likely to test a space-launch vehicle (SLV) by 2010 , and that this SLV could then be converted to an $\mathrm{ICBM}^{29}$ capable of delivering a several-hundred kilograms payload to the United States.

Iran currently has Scud missiles with ranges up to about $500 \mathrm{~km}$. It has also sought to acquire China's M-9 (600 km/500 kg) and M-11 (300 km/500 kg) missiles. And, in 1998, Iran tested its own Shabab-3 missile which is based on the North Korean No Dong missile. This missile has a range of $1300 \mathrm{~km}$, allowing it to attack most of the Middle East, including Israel.

\footnotetext{
${ }^{25}$ National Intelligence Council, op. cit., p. 4.

${ }^{26}$ Ibid.

${ }^{27}$ "Iran is developing weapons of mass destruction. It has a nuclear energy and weapons program, which aims to design, develop, and as soon as possible produce nuclear weapons." Executive Summary of the Report of the Commission to Assess the Ballistic Missile Threat to the United States, July 15, 1998.

${ }^{28}$ National Intelligence Council, op. cit., p. 4.

29 "Nations with SLVs could convert them into ICBMs relatively quickly with little or no chance of detection before the first flight test. Such a conversion would include the development of a reentry vehicle (RV). A nation could buy an SLV with the intent to convert it into an ICBM; detection of the sale should provide a few years of warning before a flight test, although [the Intelligence Community is] not confident that [it] would detect a covert sale." Ibid., p. 5.
} 
Iraq

Although the Gulf War and subsequent United Nations actions destroyed much of Iraq's missile infrastructure, the intelligence community believes that Iraq could test an ICBM (capable of reaching the United States) during the next 15 years. ${ }^{30}$ This capability could come from acquisition of Taepo Dong or No Dong missiles from North Korea. It is also possible, although less likely, that it could build an ICBM using SCUD components.

${ }^{30}$ Ibid., p. 4. 


\section{East Asia}

Today, the United States remains committed to a policy of "engagement" in the AsiaPacific region as exemplified by its decision to maintain 100,000 military personnel $^{31}$ in the area for the foreseeable future. The goal of this policy is to maintain peace and stability throughout the whole region.

\subsection{Japan}

It is U.S. policy to maintain a close military alliance with Japan. A central element of this alliance has been America's promise to retaliate against any nuclear attack on Japan. Under some circumstances, if Japan should lose confidence in the U.S. deterrent, it could lead to the weakening or breaking of the alliance and possibly to Japan developing and deploying nuclear weapons of its own.

During the Cold War, America's nuclear umbrella over Japan was never really in doubt. For example, Morton Halperin, director of the Policy Planning Staff at the State Department, has noted that "Given the lack of any clear threat to Japan and the importance of the United States to Japan, few Japanese leaders have argued that more needed to be done to prevent nuclear threats to Japan. Given the conventional balance in Asia, the question of whether nuclear weapons should be used in response to conventional attacks has never been in the forefront of the debate. Neither the Russians nor the Chinese could have any doubt that an attack on Japan would be viewed as an attack on the United States, and so the U.S. nuclear threat was seen to be sufficient deterrent." 32 Whether this was actually true in the case of the Soviet Union is unclear, since the Soviet Union would have (for most of this period) been able to retaliate against a U.S. nuclear attack. However, since the threat of a Soviet attack on Japan was always minimal or non-existent - and perceived as such by all parties - the credibility of a deterrent to a Soviet threat never was brought under careful scrutiny.

Since in the post-Cold War world there are few if any direct threats to Japan, there should (in principle) be even less concern about the credibility of the U.S. nuclear deterrent. Indeed, because of the lack of a threat, many consider the U.S.-Japanese Mutual Security Treaty an alliance in search of a mission. However, the United States considers Japan to be the linchpin of U.S. security strategy elsewhere in the Asian-Pacific area.

To cement this relationship, a revised set of Defense Guidelines was issued in September 1997. The effect of the Guidelines was to more deeply enmesh Japan in the carrying out of U.S. strategy in Asia. "For instance, the revised Guidelines outline Japanese rear area support to U.S. forces responding to a regional contingency. This support may include providing access to airfields, ports, transportation, logistics, and medical support." 33 To critics, this reveals the agreement's true purpose which is an "attempt to recreate Japan as

\footnotetext{
${ }^{31}$ There are about 80,000 ground and Air Force personnel in Japan and South Korea, and 20,000-30,000 naval personnel in the fleet stationed in the Western Pacific.

${ }^{32}$ Morton Halperin, "The Nuclear Dimension of the U.S.-Japan Relationship," The Nautilus Institute, 1998, http://www.nautilus.org., p. 18.

${ }^{33}$ Department of Defense, The United States Security Strategy for the East Asia-Pacific Region 1998, p. 5.
} 
a 'privileged sanctuary' for American military operations outside of Japan, just as it was during the Korean, Vietnamese, and Gulf Wars." ${ }^{34}$

However, in East Asia, the conditions under which those wars were fought are now quite different. Unlike in the past, China and perhaps North Korea in the next decade will have the capability to launch nuclear or biological attacks against the United States homeland, as well as strike at U.S. forces and its allies in Asia, including Japan.

\subsubsection{Chinese Threats}

China probably poses no direct threat to Japan, since there are no major areas of conflict between the two countries. However, Japan could find itself under threat because of its alliance with the United States. For example, if Taiwan declared its independence and China took military action against Taiwan, the United States may find itself drawn into a war with China. At that point, China (which has already warned Japan that the U.S.Japanese alliance must not encompass Taiwan ${ }^{35}$ ) might threaten Japan with a missile attack if it allows the United States to use Japan as a staging area for its war against China.

These threats would probably not be against U.S. bases, but against Japanese targets in order to coerce Japan. Of course, as a matter of policy, the United States claims that it would retaliate against China if Japanese targets were struck. But since China would not be targeting U.S. forces with nuclear weapons, the United States would be in the position of initiating nuclear strikes against the Chinese homeland without itself (or its forces) having been attacked with nuclear weapons. If China is in a position to retaliate with nuclear weapons against the U.S. homeland, would the U.S. threat be credible to China or, perhaps just as importantly, to Japan?

When (during the Cold War) there was no serious threat of a nuclear attack on Japan, the Japanese were generally quite content to accept the reliability of America's nuclear umbrella. Today, not everyone in Japan is convinced. For example, Kumano Kaneko, former director of the Nuclear Energy Division of the Foreign Ministry, argues that "[a]ssuming that Japan were to suffer a nuclear attack, the United States is highly unlikely to use its nuclear arms to defend Japan unless American forces in Japan were exposed to extreme danger. It is also safe to say that the United States will not use nuclear weapons unless the country itself (including Hawaii) is directly struck.... As Henry Kissinger put it bluntly, 'abandoning an ally risked eventual disaster, but resorting to nuclear war at the side of any ally guaranteed immediate catastrophe."

\footnotetext{
${ }^{34}$ Chalmers Johnson, "Old Military Alliance Repackaged Threatens Asian Stability," Japan Times, September 25, 1997.

${ }^{35}$ In 1998, Chinese Foreign Ministry spokesman Zhu Bangzhao warned that "China firmly opposes any direct or indirect activities to include the Taiwan Straits in the scope of the Japan-U.S. security cooperation relation.... [Such activity] will be resolutely opposed by the Chinese government and the Chinese people." "Japan-U.S. Security Moves Must Keep Off Taiwan Straits," April 30, 1998, http://www.chinaembassy.org.

${ }^{36}$ Kumano Kaneko, "Japan Needs No Umbrella," The Bulletin of the Atomic Scientists, March/April 1996, Vol. 52, No. 2. The Kissinger quote is from Diplomacy, Simon \& Shuster, 1994, p. 608.
} 
Kissinger's point may be even more relevant today. During the Cold War the rationale for U.S. commitments around the world and for taking risks was to thwart an international movement that was thought to threaten the very existence of the United States and indeed Western Civilization. But that worldwide threat no longer exists. While what happens in Asia is still viewed as important by U.S. policymakers, the context has completely changed - it is no longer a life and death struggle. What seemed vital to U.S. survival, no longer is.

What risks will the United States take to secure only 'important' interests? Will it risk major destruction of the homeland for these less than vital issues? And will the American public and Congress support such risks if the reality of the threat of nuclear retaliation by China (or any other nuclear-armed state that the United States might threaten to attack) is made clear? While they might continue to take such risks, it is not self-evident, and the situation could raise many doubts in Japan. Thus, perhaps paradoxically, the credibility of the U.S. nuclear umbrella over Japan may appear weaker to the Japanese in the supposedly less dangerous post-Cold War world.

\section{START III Force Levels}

Does the credibility of the umbrella depend on the force levels of START III? It seems unlikely that it depends on whether the United States has 2500 strategic nuclear warheads or 1500 . China has only a minimum deterrent strategy and force. It cannot prevent the United States from striking it with nuclear weapons, ${ }^{37}$ even if the United States has "only" 1500 warheads. ${ }^{38}$ China's strategy would be based on the calculation that the United States would not be willing to risk the destruction of a few - or few tens - of its major cities and thus would be deterred from attacking in the first place. Given the political realities and the relative stakes at risk - the loss of Taiwan could be a regime threatening event in China's view, but in reality would not affect U.S. or Japanese security since the United States already generally concedes ownership of Taiwan to China - the Chinese strategy could be quite credible, particularly to Japanese policymakers. $^{39}$

\section{Damage Denial?}

Of course, if it were clear that the United States could prevent damage to itself, perhaps by a combination of an effective National Missile Defense and counterforce targeting, then the nuclear umbrella would unlikely come in to question. But just what are the prospects of this?

When one speaks of counterforce and missile defenses, it is usually in the context of a "damage-limiting" strategy. If a peaceful United States is attacked out-of-the-blue by some aggressor state (an unlikely prospect if the United States maintains a capability to retaliate), then a damage-limiting strategy hopes to do the best it can to limit the

\footnotetext{
${ }^{37}$ Since China could not disarm the United States even in a surprise attack, a Chinese first strike would seem unlikely, unless for some reason they thought that nuclear war was inevitable.

${ }^{38}$ Although no analysis of the Chinese infrastructure was done, it seems likely that the explosion of 50 to 100 nuclear weapons on major political, economic, and cultural centers could cause enormous destruction, possibly bringing on chaos and economic and political collapse.

${ }^{39}$ Japanese policymakers may be particularly reluctant to become involved since the treaty in which the PRC and Japan normalized their diplomatic relations specifically stipulates that Taiwan is a part of China.
} 
destruction against the U.S. homeland. The strategy is not expected to be perfect, but only to reduce the damage from what could have been the objective of the aggressor.

However, the U.S. initiation of a nuclear war is quite a different matter. Will it be politically feasible for the United States to initiate nuclear strikes against China for less than vital interests unless there is very high confidence that the retaliatory damage that the United States would suffer would be zero? Would any President (politically or morally) be willing to start a nuclear war with a country over some non-vital issue unless he knew with utmost certainty that it would not result in the destruction of even one major U.S. city, let alone 10 or 20 cities?

The National Missile Defense is designed to handle only relatively small threats from "rogue" states or a small accidental launch. Even if the anticipated retaliatory strike from China were very small, who would be able to guarantee to the President that a defense system that had never been tested in combat would be a hundred percent successful? Would the President take that chance?

But, of course, the situation is likely to be worse than that. China, in the future, is unlikely to put itself in a position where it can be disarmed by the United States. In the past, it may have evaluated the U.S. threat as being relatively small. However, as retired U.S. diplomat J. R. Bullington recently noted, the war against Serbia has changed that: "Seen through Chinese eyes, Kosovo demonstrated that the United States believes it has the right to intervene in the affairs of sovereign states without United Nations endorsement and to redefine national boundaries for moral humanitarian reasons. With ongoing insurrections in Tibet and Zinjiang and unwavering determination to keep Taiwan as part of China, the Chinese see themselves as prime U.S. targets. These new American policies, they believe, could result in U.S. participation in the fragmentation of China and return to the humiliating foreign domination of the past." ${ }^{40}$ Thus, China is likely to make every effort to overcome any threat to its retaliatory force. It is already doing this with its deployment of mobile ICBMs. Moreover, China will undoubtedly feel compelled to deploy enough warheads to overwhelm any U.S. NMD system.

\subsubsection{North Korean Threats}

If war broke out on the Korean Peninsula, the United States (just as in 1950) would undoubtedly like to use Japanese air and naval bases to support its war effort in Korea. However, now North Korea has chemical and biological weapons and possibly the material for one or two nuclear weapons. Over the next decade, the North Koreans may, depending on many factors, completely break out of the nuclear control regime and try to produce a number of nuclear weapons. But even if they do not, biological weapons (and to a lesser degree chemical weapons) have the capability to do great harm to civilian populations.

Thus, by the end of the decade, North Korea (if it still exists) may be in a position to launch numerous missiles carrying weapons of mass destruction at Japan and a small number of such weapons at the United States. If North Korea threatened Japan over the

\footnotetext{
${ }^{40}$ J. R. Bullington, "The Coming American Retreat," American Diplomacy, Autumn 1999, Vol. IV, No. 4.
} 
use of Japanese bases by U.S. forces attacking North Korea, Japan would (as with threats by China) face a serious political crisis.

In principle, if the United States builds an NMD system, it might be able to plausibly argue that it could protect itself against a small attack from North Korea. Whether the President would actually take this risk and initiate nuclear strikes against North Korea (following an attack on Japan) is unclear and would depend on too many factors to analyze beforehand. But the credibility of the U.S. threat might be marginally better with the Japanese than in the case of Chinese threats. On the other hand, the North Koreans may be seen as truly desperate with little to lose, and thus their threats against Japan could be very credible to the Japanese. Of course, if the North Koreans develop and demonstrate countermeasures to the NMD - such as small BW bomblets that are released after the missile leaves the atmosphere ${ }^{41}$ - the credibility of U.S. threats would be minimal, since the Japanese would probably not believe that the U.S. would risk massive civilian casualties in a dispute over a small, non-strategic country in Asia.

If the North Korean threat were relatively small, Japan might be able to deploy its own ballistic missile defense system (perhaps in coordination with U.S. theater missile defenses ${ }^{42}$ ). Again, with North Korea, a defense might have more credibility than against China, which could probably overwhelm the system with missiles and countermeasures. However, even if the defense system were deemed to be very good, it is unlikely to be completely successful against even North Korea (and with effective countermeasures, the defense could be next to useless). Japan may not be willing to take even a few hits with weapons of mass destruction to support what would be seen as a U.S. war (not a Japanese war) against North Korea.

\subsubsection{Proliferation}

Thus, under the circumstances where potential opponents can deliver weapons of mass destruction to the United States and Japan, the U.S. nuclear umbrella over Japan may increasingly appear to be an insufficient guarantee to warrant Japan's continued involvement in what Japanese leaders may come to consider areas (the Chinese-Taiwan or Korean disputes) that Japan has no intrinsic stake in - at least not to the degree of risking nuclear or biological attack. This could mean a break in the U.S.-Japanese alliance or at least a selective partnership that would not allow the use of Japanese territory to support U.S. wars against nuclear-armed adversaries. As a step in this direction, the opposition Democratic Party of Japan has already called for an "alliance without U.S. bases," where, although the alliance would be maintained, U.S. forces would not be stationed in Japan. With this arrangement, it would be much easier for Japan to extricate itself from any Asian war in which the United States might find itself.

Would a loss in confidence in the U.S. nuclear umbrella lead to the acquisition of nuclear weapons by Japan? Not necessarily, since there are serious historical and political

\footnotetext{
${ }^{41}$ The hundreds of targets would overwhelm the NMD system. For a discussion of this and other possible countermeasures, see George N. Lewis, Theodore A. Postol, and John Pike, "Why National Missile Defense Won't Work," Scientific American, August 1999, pp. 36-41.

${ }^{42}$ The United States and Japan signed an agreement on August 13, 1999 to undertake a joint research program on ballistic missile defenses.
} 
constraints in Japan on obtaining nuclear weapons. However, the Japanese anti-war Constitution does not explicitly rule out nuclear weapons. Once the interpretation of the Constitution was expanded to allow the maintenance of "defense forces," any particular weapon, even nuclear ones, could be interpreted as defensive. Moreover, the development of nuclear weapons is clearly within Japan's reach technically.

The debate over a nuclear deterrent is not new in Japan. As Morton Halperin noted, "Throughout the postwar period, Japanese leaders quietly debated the question of whether Japan should develop an independent nuclear capability. This debate was not centered around the credibility of the U.S. deterrent.... [M]ost Japanese who leaned toward advocating a Japanese nuclear capability took this position because they believed such a position would permit Japan to end the security relationship with the United States and to assert an independent role in the world." ${ }^{\prime 43}$ There were several obstacles to regaining this independence through proliferation: its rejection by the Japanese public, fear of the reaction of Japan's trading partners in Asia, and the realization that it would be very difficult to maintain a secure second-strike capability against the Soviet Union.

The end of the Cold War has changed at least one of these restraints. The Soviet Union no longer exists, and Russia is not at present viewed as a threat. Moreover, as the number of strategic weapons that Russia deploys comes down, Japan may come to believe that it can deploy a survivable deterrent against Russia and China. If START III locks Russia into a force of 1500 or so strategic weapons, this could be further encouragement to Japan, since it would not have to be as concerned about a later expansion of strategic warheads by Russia.

Of course, the political objections to nuclear weapons would still hold,$^{44}$ and it would require a significant shift in public opinion to allow the Japanese government to seriously consider a nuclear option. There are perhaps a number of events that could bring this about. One possibility depends on political developments in Korea. Today, North Korea itself is not viewed as a particular threat, especially since it is diplomatically isolated and on the verge of economic collapse. During the Cold War, Korea was called "a dagger pointed at the heart of Japan" because of the concern that the Soviet Union might eventually occupy it. Today, there is little possibility of a foreign power controlling Korea.

However, Japanese attitudes might change dramatically if Korea was reunified under the South Korean government and that highly industrialized and wealthy government embarked upon a policy of producing nuclear weapons. Because of Japan's brutal occupation of the country dating from the Russo-Japanese War until the end of World War $I I,{ }^{45}$ a nuclear-armed united Korea might well be considered a potential threat requiring counteractions.

\footnotetext{
${ }^{43}$ M. Halperin, op. cit., pp. 18-19.

${ }^{44}$ For example, Vice Defense Minister Shingo Nishimura of the Liberal Party was forced to resign in October 1999 after he urged (in a magazine) the Diet to consider arming Japan with nuclear weapons. Nishimura was denounced by all opposition Democratic, Social Democratic, and Communist parties as well as by the governments of China and South Korea.

${ }^{45}$ Japan tried to suppress the national identity of the Koreans through education, enforced name changes, and the suppression of the Korean language.
} 
Alternatively, if, as discussed above, the U.S.-Japanese alliance comes to be seen more as a security threat than as a guarantee (due to its commitment to support U.S. wars), there could eventually be a break in the alliance. If that occurred, many Japanese may come to believe that, even though there are no great security threats to Japan, an economic superpower like Japan, in order to take its rightful position in the world, must have the other defining attribute of a superpower - nuclear weapons. ${ }^{46}$

Whether any of this will come about is very uncertain, depending heavily on the further evolution of the political situation in East Asia. But whatever the result, it is unlikely to depend heavily on whether START III limits forces are reduced to 1500 warheads, except to the extent that it might encourage Japan to believe that it could be competitive with Russia and China, because it could now more easily deploy a modest secure second-strike deterrent force.

\subsection{Taiwan}

There is little reason to believe that U.S. extended nuclear deterrence applies to Taiwan. The Taiwan Relations Act of 1979 commits the United States to supply Taiwan with adequate defensive weapons and declares that the United States would view any Chinese military action against Taiwan with "grave concern." However, the Act stops short of extending an unconditional security guarantee to Taiwan.

The United States has never threatened to use nuclear weapons if China were to invade Taiwan (nor has it even unambiguously said that it would intervene using conventional weapons). As to the possibility of a nuclear attack on Taiwan by the PRC, this seems extremely remote. Since Taiwan is considered by the PRC to be a province of China, it would be attacking its own people. Such an attack would risk de-legitimizing the Beijing regime in the eyes of Chinese people as perhaps nothing else could.

Thus, perhaps the more important issue from Taiwan's viewpoint is not extended nuclear deterrence, but whether the United States would intervene militarily at all if Taiwan were threatened with invasion. There are (at least) two sets of circumstances for such a crisis: China grows impatient with waiting for re-unification and decides to take unilateral military action or Taiwan decides that its best hope is to declare its independence as a free nation, independent of China.

In the case of an "unprovoked" attack by China, there could be considerable sentiment in the U.S. Congress to come to the aid of Taiwan, ${ }^{47}$ which has been under the protection of the United States (in one form or another) since the 1950s. However, the United States has never gone to war (directly) with a nuclear-armed opponent who could potentially destroy a number of U.S. cities, causing the deaths of millions perhaps along with economic and political chaos. As China builds a larger and more secure intercontinental

\footnotetext{
${ }^{46} \mathrm{Japan}$, with the second largest economy in the world, is already a strong conventional power, spending more on defense than all but two countries in the world. Its air force (which provides all of its own defense of the islands without U.S. support) is the most powerful in Asia, and it has the second largest blue water navy in Asia.

${ }^{47}$ However, "a recent NewsMax.com/Zogby poll found that more than two-thirds of Americans opposed defending Taiwan." Doug Bandow, "Keeping Peace in the Taiwan Strait," Cato Institute Daily Commentary, March 24, 2000.
} 
nuclear force, Taiwan might increasingly doubt that the United States would come to its aid.

If Taiwan were to declare its independence from China, this would certainly precipitate a crisis in which strong actions could be expected from the CPR ranging from a blockade to invasion. If China invaded, it would undoubtedly pay a very high price militarily (Taiwan has a very strong homeland defense force) and diplomatically. However, China has consistently said that this is the one action by Taiwan that was absolutely intolerable and that every other goal of the Chinese government (economic, diplomatic, political) would be put aside to prevent secession.

Since it is also against U.S. policy for Taiwan to declare its independence and there is no unconditional security guarantee to Taiwan, it is even more uncertain how the United States would react to an invasion under those circumstances. ${ }^{48}$ Congressional opinion is likely to be much more divided in this case. Nevertheless, the U.S. political leadership (depending on the international situation at the time) could come to the conclusion that its political credibility was on the line, and the United States could be drawn (however reluctantly) into the conflict.

\section{START III}

Although extended nuclear deterrence is not likely to play a role in the defense of Taiwan, might deep cuts in U.S. nuclear weapons play a major role in a decision of whether or not to intervene at all (with conventional forces)? China is unlikely to initiate a nuclear strike on the U.S. homeland, since, as noted above, even with a U.S. arsenal of only 1500 strategic warheads, China could not disarm the United States and thus could not physically prevent the United States from responding to a nuclear attack. On the other hand, particularly later in the decade, the United States will unlikely be able to disarm China either.

The reluctance to get involved in a China-Taiwan conflict is thus not likely to depend on the number of strategic weapons the United States has, but on the fact that it would be engaged in a war with a country that it could not prevent from attacking it with nuclear weapons. A large-scale conflict between nuclear powers has never been fought and the consequences are unpredictable. While a Chinese first-strike on the U.S. homeland would be irrational, any war has the potential for unexpected and undesired actions and for uncontrolled escalation in the level of violence. ${ }^{49}$ For example, if the Chinese leadership thought that they were losing the war and if in their view such a loss might threaten their continued control of power, they could out of desperation launch nuclear attacks at U.S.

\footnotetext{
${ }^{48}$ To critics, U.S. policy seems confused and destabilizing. For example, according to Doug Bandow and Ted Galen Carpenter: "By rejecting Taiwan's claim to independent status, Washington has undercut the credibility of its own implicit threat of military intervention. The administration's affirmation of Beijing's position encourages the PRC to act provocatively. Yet, Washington's implicit defense guarantee allows Taipei to act in the expectation of U.S. military support in case of trouble. This could lead to a risky game of international chicken, the result of which could be a catastrophic crisis triggered by a formal Taiwanese declaration of independence." "Risking War for Taiwan?" Cato Institute Daily Commentary, January 6, 2000.

${ }^{49}$ Of course, Chinese generals have been quoted as saying that if the United States attacked China (presumably with conventional weapons), it would have to expect a nuclear retaliation by China. Their skepticism about the willingness of the U.S. to attack is expressed in the question "Would the United States trade Los Angeles for Taipei?"
} 
forces engaged in combat. If the U.S. responded in kind, a cycle of escalation that might be very difficult to control would be underway.

\section{Proliferation}

Because of the unpredictability of U.S. actions, Taiwan could be a strong candidate for nuclear proliferation, particularly if its leaders decided that a declaration of independence was the right course of action. But even if Taiwan had no plans to become a separate independent state, it could in the next decade decide that it needed some hedge to maintain its freedom from Beijing. Nuclear weapons could be that hedge. ${ }^{50}$

While Taiwan depends on a number of nuclear power plants for a large portion of its electrical power, it does not at present have a reprocessing capability. Moreover, the plants as currently run would produce reactor-grade plutonium, which could be problematic for use in nuclear weapons. Thus, it would probably take a number of years before nuclear weapons could actually be produced. During that time, if the United States learned of the plans, great political pressure would undoubtedly be brought against Taiwan to prevent proliferation. Of course, if Beijing learned of the program, an even more violent reaction could be expected, including military attacks on the facilities. ${ }^{51}$

Thus, nuclear proliferation would be a very risky course of action for Taiwan. It seems likely that it would be undertaken only under the direst of circumstances or if the Taiwanese leadership became committed to national independence. At any rate, the decision is unlikely to be connected to the outcome of any START III Treaty negotiations.

\subsection{Republic of Korea (ROK)}

What role, if any, America's nuclear forces play in deterring a conventional attack by North Korea on South Korea is unclear, but it is unlikely to depend on whether the United States has 2500 strategic warheads or 1500 . As for deterrence of a nuclear (and perhaps biological) attack, America's nuclear umbrella over South Korea remains very credible because U.S. forces are on the ground in South Korea and committed to its defense. Thus, as long as the United States remains committed, the likelihood of South Korean nuclear proliferation would appear to be minimal.

It is possible of course that a North Korea armed with ICBMs carrying nuclear or biological warheads might try to blackmail the United States into withdrawing from South Korea. The success of that strategy is unlikely to depend on START III force levels, but on whether the United States can defend itself and upon the political calculations at the moment.

\footnotetext{
${ }^{50}$ For example, a news item reported in December that "Taiwan has upped the stakes in its dispute with China by openly discussing long-range missiles and nuclear weapons. Taiwan has the technical and industrial abilities to do both in short order. Taiwan politicians say that the country needs this capability to prevent first strike attacks by China, or nuclear blackmail. There is also fear in Taiwan that America might back off if China went after 'Taiwan and threatened the use of nuclear weapons against U.S. targets if America attempted to intervene." "Taiwan Threatens to Go Nuclear," For Your Eyes Only Newsletter, December 13, 1999.

${ }^{51}$ According to a Department of Defense report to Congress, one of the conditions under which China refuses to rule out the use of force against Taiwan is "Taipei's acquisition of nuclear weapons." "The Security Situation in the Taiwan Strait," Report to Congress, February 1999.
} 
UCRL-ID-139508

Page 23

Of course, if the United States decided to disengage from the direct defense of South Korea (perhaps citing the fact that South Korea has over twice the population of the North and more than 25 times its wealth ${ }^{52}$ ), South Korea could decide that it needed nuclear weapons to deter the possible use of nuclear or biological weapons by the North. This decision also would obviously not hinge on the outcome of START III.

52 The population of South Korea is $46,885,000$ and that of North Korea is $21,387,000$. In 1998, it was estimated that the GDP of South Korea was $\$ 585$ billion and that of North Korea was $\$ 22$ billion. 


\section{The Middle East}

The Middle East remains a highly volatile region. Because of the Gulf War with Iraq, the United States has become more deeply involved militarily in the region, increasing the possibility of future U.S. military clashes there. Because there is a substantial risk of proliferation of weapons of mass destruction and long-range delivery systems in this region in the next 10 to 15 years, the risk involved with U.S. intervention could become substantially higher than in the past. Thus, the credibility of U.S. commitments to this region could come to be questioned. However, whether this would result in the further ${ }^{53}$ proliferation of nuclear weapons on the part of U.S. friends and allies is uncertain.

\subsection{Extended Deterrence}

Current U.S. military deployments in the Middle East are primarily in connection with the aftermath of the Gulf War. Once UN sanctions are lifted against Iraq, it is unclear whether land-based deployments will continue for an indefinite period, although a naval presence in the region can always be relatively quickly achieved. While the United States is concerned about the fate of Israel, Saudi Arabia and the Gulf States, there is no formal treaty obligations to come to the aid of any country in the region.

Nevertheless, U.S. foreign policy goals are likely to continue to emphasize maintaining stability in the region, and this will probably continue to lead to U.S. policymakers favoring military interventions if war should threaten U.S. friends in the region.

However, the United States has never indicated that it would use nuclear weapons to try to deter a conventional attack in the region, and thus extended nuclear deterrence has at most a limited application there - to deter the use of nuclear and perhaps biological and chemical weapons.

But, of course, if potential opponents had nuclear, biological, or chemical weapons that they could deliver on the U.S. homeland (as opposed to just in the region), the calculation of the merits of intervention might change. Thus, there are two issues: would the United States be deterred from intervention, and, if it did intervene, could the United States credibly use nuclear threats to deter the use of weapons of mass destruction in the region if the enemy had the capability to retaliate against the U.S. homeland?

On the face of it, the risk of a nuclear or BW attack on the United States if it militarily intervened might appear to be relatively low, unless the United States initiated nuclear attacks or if the enemy felt its regime was collapsing as a result of U.S. intervention. Nevertheless, if the other side had a capability to strike at the United States with weapons of mass destruction, there could be serious questions about whether the President would be willing to risk American cities - perhaps to maintain some feudal monarch on his throne, as in Kuwait - and whether the American people or Congress would tolerate the risk, no matter how small.

Of course, the potential effectiveness of U.S. counterforce targeting and a U.S. National Missile Defense system (if it is built) would play a role in the President's calculations. Thus, any regional power that planned to counter the United States would also have to plan on making its forces survivable and developing penetration countermeasures.

\footnotetext{
${ }^{53}$ Israel is of course assumed to already have nuclear weapons.
} 
UCRL-ID-139508

Page 25

However, even without these efforts, the United States would have to be concerned about the inherent threat of clandestine deployment of weapons of mass destruction in the United States, circumventing any U.S. counterforce targeting or defenses.

\section{START III}

Again, whatever the answer to the question of the credibility of U.S. extended deterrence or willingness to intervene, it would appear that the answer is unlikely to depend on the outcome of START III negotiations. The number of weapons required to deter a nuclear (or chemical or biological) attack on the United States or deter other aggressive actions by a regional power - to the extent that such actions are deterrable - should be quite modest. For example, it is likely that 50 or fewer nuclear weapons could virtually annihilate any small regional power. This is not to suggest that carrying out such a threat should form the basis of U.S. policy. The point is that if the threat of an attack by 50 nuclear weapons will not deter a regional power, then more weapons are unlikely to be any more successful..$^{54}$

\subsection{Proliferation}

Israel, America's primary friend in the region, does not depend on U.S. intervention to protect it. Moreover, Israel is assumed by everyone to already have a significant nuclear arsenal.

Until the Gulf War, the Arab states in the region never expected the United States to come to their direct aid with military deployments. To many of these states, U.S. support in the event of war might seem tenuous at best relying as it does on the attitude of the U.S. President at the time, on the Congress, and on the reaction of the American people. If potential adversaries in the region, primarily Iran and Iraq, developed nuclear weapons or other weapons of mass destruction along with long-range delivery systems, countries aligned with the United States could come to doubt the (unstated) U.S. commitment to come to their aid. Their course of action in that event could be varied: joining together to form a united front, seeking accommodation with their enemies, or developing weapons of mass destruction of their own as a counter-threat deterrent. These weapons would most likely be chemical or biological rather than nuclear, since they would be much easier to produce and would not run counter to the nuclear non-proliferation regime. Of course, some of these states might try to develop these weapons anyway as a way to offset Israel's nuclear weapons.

\footnotetext{
${ }^{54}$ For a discussion of the view that some "rogue states" may not be deterrable by nuclear threats see Keith B. Payne, Deterrence in the Second Nuclear Age (University Press of Kentucky, 1996).
} 


\section{Conclusions}

While the post-Cold War world could see decreased confidence in the U.S. policy of extended deterrence, this may have little to do with the terms of a START III agreement. The credibility of extended deterrence will probably depend far more on the specific capability of the enemy to retaliate against the U.S. homeland than on the number of strategic weapons the United States possesses (i.e., 1500 vs. 2500). As to a decision of an individual ally to acquire nuclear weapons, confidence in America's nuclear umbrella is, while important, likely to be only one of many geopolitical factors that would enter into such a decision.

In Europe, NATO is quite capable of defending itself against a conventional attack without invoking U.S., British, or French nuclear weapons. Even a very aggressive Russia would have serious doubts about initiating nuclear strikes against NATO, since it would start a chain of actions that could end in the destruction of the Russian state. Under foreseeable circumstances, there is little incentive for any European country to break from its allies and deploy its own nuclear weapons.

In Japan, there is no real threat of a conventional force invasion, and thus the threat to use U.S. nuclear weapons to prevent such an attack does not come into play. However, if the U.S. became embroiled in a war with China or North Korea, these countries could threaten Japan with nuclear or biological weapons to prevent Japan from allowing the United States to use Japanese bases to support attacks on China or North Korea. These threats, particularly from China, might be taken very seriously by the Japanese. And since the United States probably could be struck in retaliation, the credibility of the U.S. deterrent could be quite low with the Japanese, independently of whether the United States had 1500 or 2500 strategic warheads.

If the threat of conflict in Korea or the Taiwan Strait should increase in coming years, entanglements in U.S. commitments to South Korea and Taiwan could come to be seen by the Japanese as dangerous to their security. This could lead to a weakening of the U.S.-Japanese alliance. If the alliance were broken, Japan might seek to become a nuclear power itself, depending on the geopolitical circumstances.

As long as U.S. forces are stationed in Korea, South Korea is unlikely to lose confidence in the U.S. deterrent and seek its own nuclear weapons. If the United States decided to disengage from the direct defense of South Korea, the ROK could decide that it needed nuclear weapons to deter the possible use of nuclear or biological weapons by the North. This decision also would obviously not hinge on the outcome of START III.

The United States has no explicit commitment to come to the defense of Taiwan if attacked by China, although it could easily do so (depending on the political circumstances). However, the United States would unlikely resort to nuclear weapons to defeat a conventional attack, and the threat of a nuclear attack by China on what it considers one of its provinces seems very low. Thus, the more likely issue is whether the United States would be reluctant to become embroiled in a major war with a nucleararmed adversary (capable of striking the U.S. homeland) over what China might consider critical to its interests, but the United States would only consider marginal to its vital interests. The credibility of the (unstated) U.S. willingness to become engaged in such a 
war is unlikely to depend on whether the United States has 1500 or 2500 nuclear warheads. Taiwan's acquisition of nuclear weapons is likely to depend on a decision to declare its independence or on some dramatic change in Beijing's policy of seeking only a peaceful reunification.

In the Middle East, America's main ally, Israel, presumably already has nuclear weapons, and thus the question of extended deterrence and proliferation does not arise. As to the Arab states, the United States has made no explicit commitments, but based on past history it might be expected to intervene militarily in the event of aggression against U.S. friends. However, if potential aggressors such as Iran or Iraq should develop weapons of mass destruction and the capability to deliver them to the U.S. homeland, Arab states may come to doubt the willingness of the United States to intervene under such circumstances. In that case, these Arab states might try to develop weapons of mass destruction of their own or take other actions. At any rate, the loss in the confidence in the willingness of the United States to intervene is unlikely to depend on the outcome of START III, but upon the willingness of the United States to risk attack on its cities or on the assured capability of the United States to physically prevent such attacks. 